\title{
Paravertebral cervical block for osteosynthesis of humeral fracture in foal
}

\section{Bloqueio paravertebral cervical para realização de ostessíntese de fratura de úmero em potro}

\author{
Vitor Yuji Miyashiro ${ }^{1 *}$; Paulo Sérgio Patto dos Santos²; Flávia de Almeida Lucas²; \\ Flávia de Rezende Eugênio²; Juliana Regina Peiró2; \\ Daniela Scantamburlo Denadai ${ }^{1}$
}

\begin{abstract}
A modified cervical paravertebral block of the brachial plexus was performed with the aid of a nerve stimulator for osteosynthesis with four intramedullary pins in a 5-month-old colt weighing $180 \mathrm{~kg}$ diagnosed with a closed, complete, and oblique humerus fracture. Xylazine $2 \%\left(0.5 \mathrm{mg} \mathrm{kg}^{-1} \mathrm{IV}\right)$ was administered as the pre-anesthetic medication. Anesthesia was induced with ketamine $10 \%\left(2 \mathrm{mg} \mathrm{kg}^{-1}\right.$ IV) and midazolam $0.5 \%\left(5 \mathrm{mg} \mathrm{kg}^{-1} \mathrm{IV}\right)$ and maintained with isoflurane. The animal was on mechanical ventilation. The nerve block was induced with administration of ropivacaine $0.75 \%$ in the ventral branches of $\mathrm{C}_{6}$ (intervertebral space $\mathrm{C}_{5}-\mathrm{C}_{6}$ ) and $\mathrm{C}_{7}$ (intervertebral space $\mathrm{C}_{6}-\mathrm{C}_{7}$ ) and in the branches of $\mathrm{C}_{8}$ and $\mathrm{T}_{1}$ at their convergence at the cranial margin of the first rib. During the 130-min duration of the surgery, no analgesic rescue was required. In conclusion, this blockade can be performed safely and promotes numbness of the humeral and olecranon regions.
\end{abstract}

Key words: Locoregional anesthesia. Equine. Nerve stimulator.

\section{Resumo}

Realizou-se o bloqueio paravertebral cervical modicado do plexo braquial, com auxílio de estimulador de nervos, para execução de osteossíntese com quatro pinos intramedulares, em potro de 5 meses, com $180 \mathrm{~kg}$, diagnosticado com fratura fechada, completa e oblíqua de úmero. $\mathrm{O}$ animal foi submetido a anestesia com medicação pré-anestésica, xilazina $2 \%\left(0,5 \mathrm{mg} \mathrm{kg}^{-1} \mathrm{IV}\right)$ e indução anestésica com cetamina 10\% (2 mg kg-1 IV) associada ao midazolam $0,5 \%\left(0,5 \mathrm{mg} \mathrm{kg}^{-1} \mathrm{IV}\right)$. A manutenção anestésica foi feita com isoflurano, sendo sempre mantido em ventilação mecânica. O bloqueio foi feito com ropivacaína $0,75 \%$ nos ramos ventrais de $\mathrm{C}_{6}$ (espaço intervertebral $\mathrm{C}_{5}-\mathrm{C}_{6}$ ), $\mathrm{C}_{7}$ (espaço intervertebral $\mathrm{C}_{6}-\mathrm{C}_{7}$ ) e nos ramos de $\mathrm{C}_{8}$ e $\mathrm{T}_{1}$ em sua convergência na margem cranial da primeira costela. Durante os 130 minutos de duração da cirurgia, não foi necessário qualquer resgate analgésico. Conclui-se que esse bloqueio foi realizado de forma segura e promoveu insensibilidade da região de úmero e olecrano. Palavras-chave: Anestesia locorregional. Equino. Neuroestimulador.

${ }^{1}$ Residentes, Faculdade de Medicina Veterinária de Araçatuba, Universidade Estadual Paulista, FMVA/UNESP, Araçatuba, SP, Brasil. E-mail: vitor.y.miyashiro@gmail.com; daniela denadai@hotmail.com

2 Profs. Drs., Departamento de Clínica, Cirurgia e Reprodução Animal, FMVA/UNESP, Araçatuba, SP, Brasil. E-mail: patto@ fmva.unesp.br; flavialucas@fmva.unesp.br; eugeniof@fmva.unesp.br; jpeiro@fmva.unesp.br

Auhor for correspondence

Received: Nov. 07, 2018 - Approved: Aug, 27, 2019 


\section{Introduction}

In horses, many diagnostic and surgical procedures can be performed safely and properly with the combination of local anesthesia with sedation and/or physical restraint, and these tools are indispensable for the equine veterinarian (CARPENTER et al., 2017). Regional anesthesia and analgesia may be used as adjuncts to general anesthesia, promoting decreased anesthetic requirement (CARPENTER et al., 2017).

In dogs, the paravertebral cervical block is used as an alternative to the brachial plexus block. The access and local anesthetic block of the emergencies of the cervical $\left(\mathrm{C}_{6}, \mathrm{C}_{7}\right.$, and $\left.\mathrm{C}_{8}\right)$ and thoracic $\left(\mathrm{T}_{1}\right)$ nerve roots, which innervate the thoracic limbs in dogs, induce anesthesia for procedures in the scapular, humeral, and radioulnar regions (CARVALHO, 2008). Here, we report a case of paravertebral cervical block performed in a foal with a proximal humerus fracture. As the animal was young with undeveloped musculature, the anatomical structures could be more easily palpated, which is essential to perform this procedure (KLAUMANN, 2013).

Difficulties in inducing perineuronal anesthesia may lead to several clinical complications (VISCASILLAS et al., 2013). The success rate of the neuronal blockade can be increased with the use of a stimulator of the peripheral nerve, as it allows delicate positioning of the needle tip close to the nerve (IMBELLONI et al., 2001). Accurate needle placement is important to maximize the success of the blockade and minimize the incidence of complications (JOCHUM et al., 2006). This report aimed to describe the modified paravertebral cervical block technique in horses, which has not been previously reported in the literature.

\section{Case report}

A 5-month-old male quarter horse weighing 180 $\mathrm{kg}$ was treated at our veterinary hospital. Consent was obtained from the animal's owner to perform the described procedures and to use the data for publication of this report. The animal sustained a fracture of the left thoracic limb $24 \mathrm{~h}$ before and underwent an emergency therapy consisting of external limb immobilization and analgesia (flunixin meglumine $1.1 \mathrm{mg} \mathrm{kg}^{-1} \mathrm{IM}$ ). Radiographic examination revealed a complete oblique fracture in the distal third of the left humerus, which was an indication for osteosynthesis. The animal was injected with phenylbutazone $20 \%\left(4.4 \mathrm{mg} \mathrm{kg}^{-1}\right)$ immediately after the diagnosis.

After the pre-anesthetic clinical examination (Table 1), the animal was injected with xylazine $2 \%$ $\left(0.5 \mathrm{mg} \mathrm{kg}^{-1} \mathrm{IV}\right)$ as the pre-anesthetic medication. Subsequently, ketamine $10 \%\left(2 \mathrm{mg} \mathrm{kg}^{-1}\right)$ and midazolam $0.5 \%\left(0.5 \mathrm{mg} \mathrm{kg}^{-1}\right)$ were administered intravenously for induction of anesthesia, and isoflurane was administered for maintenance. The animal was intubated with the orotracheal tube 20 ET and placed on intermittent positive-pressure mechanical ventilation.

The modified paravertebral cervical block of the brachial plexus was performed with ropivacaine $0.75 \%$ at three different points with the aid of a peripheral nerve stimulator (Stimuplex HNS 12). Initially, the limb was lifted with the help of a hoist to expose the cranial margin of the first rib. The transverse process of $\mathrm{C}_{6}$ was palpated through counting of the cervical vertebrae caudal to the atlas. It corresponds to a rigid structure in the cervical region under the serratus ventralis muscle of the cervix (Figure 1), which delimits its cranial and caudal margins. Subsequently, the site was trichotomized and antiseptically prepared. A 20-G and $10-\mathrm{cm}$ nerve stimulator needle was introduced approximately $6 \mathrm{~cm}$ deep into the ventral branches of $\mathrm{C}_{6}\left(\mathrm{C}_{5}-\mathrm{C}_{6}\right.$ intervertebral space $)$ and $\mathrm{C}_{7}\left(\mathrm{C}_{6}-\right.$ $\mathrm{C}_{7}$ intervertebral space), which are immediately dorsocranial and dorsocaudal to the transverse process of $\mathrm{C}_{6}$, respectively. Electrolocation of the nerves was initiated with a stimulating current of $1 \mathrm{~mA}(2 \mathrm{~Hz} ; 0.1 \mathrm{~ms})$. When a positive response triggered (muscle contractions), the current was 
reduced, and the needle was repositioned until a positive response was obtained with a current of $0.3 \mathrm{~mA}$ and a negative response (absence of muscle contractions) with a current of 0.2 $\mathrm{mA}$, thereby avoiding intraneural application of local anesthetics. The first rib was palpated; the region immediately cranial to the scapula was trichotomized; antisepsis was performed. The needle was inserted craniocaudally immediately below the transverse process of $\mathrm{C} 7$ to reach the first rib. Subsequently, the needle was deflected medially and introduced to the length of approximately $2 \mathrm{~cm}$, and the electrolocation of the $\mathrm{C}_{8}$ and $\mathrm{T}_{1}$ branches at their convergence on the cranial margin of the first rib was performed in the aforementioned way described for the other branches. After locating the nerves, $6 \mathrm{~mL}\left(0.25 \mathrm{mg} \mathrm{kg}^{-1}\right)$ of a local anesthetic was injected in each space (Figure 1).

During the surgical procedure, no changes in the monitored parameters were interpreted as pain (Table 1). Perioperative analgesic rescue was not needed. There were no significant clinical changes in the two blood gas tests performed during the surgical procedure.

Table 1. Duration and monitoring of vital parameters in the preoperative, intraoperative, and immediate postoperative periods. HR: heart rate, $f$ : respiratory rate, SAP: systolic arterial pressure, DAP: distolic arterial pressure, MAP: mean arterial pressure, SatO2: oxyhemoglobin saturation, EtCO2: end-expiratory carbon dioxide.

\begin{tabular}{|c|c|c|c|}
\hline \multicolumn{4}{|c|}{ Basal parameters (pre-anesthetic examination) } \\
\hline HR & & \multicolumn{2}{|c|}{$60 \mathrm{bpm}$} \\
\hline$f$ & & \multicolumn{2}{|c|}{$56 \mathrm{rpm}$} \\
\hline Temperature & & \multicolumn{2}{|c|}{$38.4^{\circ} \mathrm{C}$} \\
\hline Capillary filling time & & \multicolumn{2}{|c|}{$2 \mathrm{~s}$} \\
\hline Oral mucosa staining & & \multicolumn{2}{|c|}{ Pink } \\
\hline Hydration degree & & \multicolumn{2}{|c|}{ Suitable } \\
\hline Parameters & Values & Parameters & Values \\
\hline HR (bpm) & & MAP (mmHg) & \\
\hline Maximum & 52 & Maximum & 105 \\
\hline Minimum & 43 & Minimum & 48 \\
\hline Average & $48 \pm 2.04$ & Average & $78 \pm 12.51$ \\
\hline$f(\mathrm{rpm})$ & & $\mathrm{SatO}_{2}(\%)$ & \\
\hline Maximum & 7 & Maximum & 99 \\
\hline Minimum & 7 & Minimum & 94 \\
\hline Average & $7 \pm 0$ & Average & $97 \pm 1.41$ \\
\hline $\mathrm{SAP}(\mathrm{mmHg})$ & & $\mathrm{EtCO}_{2}(\mathrm{mmHg})$ & \\
\hline Maximum & 115 & Maximum & 50 \\
\hline Minimum & 70 & Minimum & 12 \\
\hline Average & $96 \pm 10.85$ & Average & $30 \pm 6.2$ \\
\hline DAP (mmHg) & & Temperature $\left({ }^{\circ} \mathrm{C}\right)$ & \\
\hline Maximum & 90 & Maximum & 38,1 \\
\hline Minimum & 35 & Minimum & 36,4 \\
\hline Average & $66 \pm 13.33$ & Average & $37 \pm 0.38$ \\
\hline
\end{tabular}

Expired isoflurane concentration (\%)

Maximum

Minimum

Average 
continuation

Duration of surgery (h)

Duration of anesthesia (h)

Time to extubation after disconnection from the anesthesia device ( $\mathrm{min}$ )

Time to support the head after disconnection from the anesthetic device ( $\mathrm{min}$ )

Time to assume the quadrupedal position after disconnection from the anesthesia device ( $\mathrm{min}$ )

Figure 1. Anatomical illustrations of the equine cervical skeleton (DYCE et al., 2010) and musculature and emergence of the nerve branches (BUDRAS et al., 2009). Red lines: anatomical correspondence of intervertebral spaces, $\mathrm{C}_{6}$ and $\mathrm{C}_{7}$ nerve roots, and intersection of $\mathrm{C}_{8}$ and $\mathrm{T}_{1}$ roots; $\mathrm{a}$ : $\mathrm{C}_{6}$ transverse process; $\mathrm{b}$ : cranial margin of the first rib; $\mathrm{c}$ : ventral branch of the $\mathrm{C}_{6}$ nerve root (first application of ropivacaine); $\mathrm{d}$ : ventral branch of the $\mathrm{C}_{7}$ nerve root (second application); e: intersection of the nerve branches of $\mathrm{C}_{8}$ and $\mathrm{T}_{1}$ (third application).

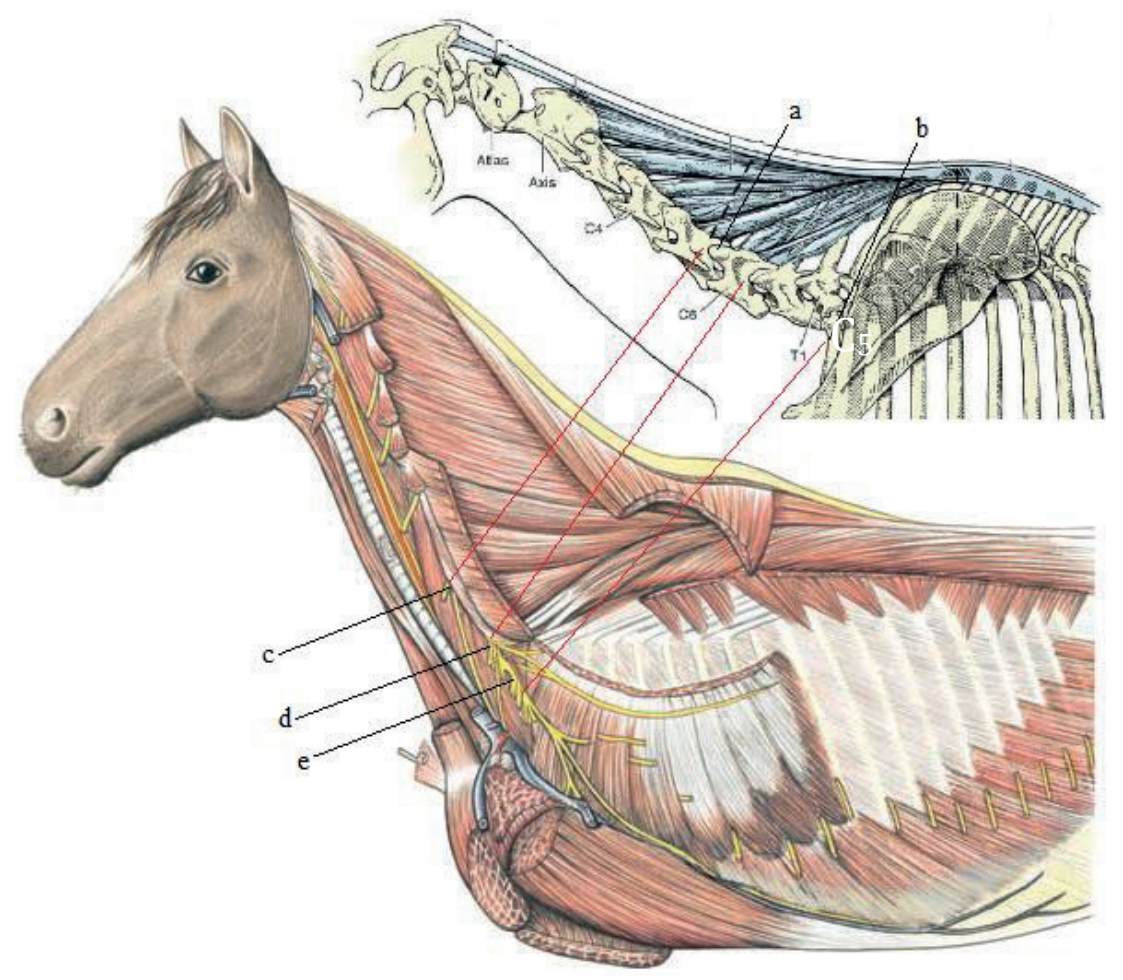

The surgical procedure consisted of open fracture reduction. Twenty minutes before the end of the surgery, morphine $1 \%\left(0.1 \mathrm{mg} \mathrm{kg}^{-1}\right)$ was administered via an epidural injection to promote postoperative analgesia, and phenylbutazone $20 \%$ (4.4 $\mathrm{mg} \mathrm{kg}^{-1} \mathrm{IV}$ ) was administered as an aid to the analgesic therapy.

At the end of the surgery, the animal was weaned from the controlled ventilation, and isoflurane was discontinued. When two successive spontaneous breathing movements were noted, the foal was disconnected from the anesthetic circuit and removed from the operating table. Subsequently, it was transferred to the recovery room. Shortly after assuming a quadrupedal position, a proprioceptive deficit of the operated limb was noted. 


\section{Discussion}

To promote minimal systemic changes and balanced anesthesia, the locoregional anesthesia technique was employed. It provides stability of parameters during the surgery without the need for systemic analgesics (MORAES et al., 2013). The use of analgesic drugs, such as xylazine and ketamine, in the preoperative and perioperative periods could have influenced the stability of the parameters during the surgery. However, neither xylazine (MURRELL, 2017) or ketamine (BERRY, 2017) has a duration of action that is sufficiently long to last the entire surgical procedure.

The minimum values of arterial pressure were attributed to the anesthetic depth, as they occurred when the concentration of the inhaled anesthetic was higher $(1.5 \%)$, and there was loss of eyelid and corneal reflexes. Eighty-five minutes after beginning the surgery, the animal presented with the peak arterial pressure value, which could be interpreted as superficialization of the anesthetic plane; the animal presented with nystagmus and increased eyelid reflexes. To deepen the anesthesia, $10 \%$ ketamine $\left(0.5 \mathrm{mg} \mathrm{kg}^{-1} \mathrm{IV}\right)$ was administered, and isoflurane vaporization was increased. The same events occurred $30 \mathrm{~min}$ later, and the ketamine administration was repeated.

The lack of reports on paravertebral cervical block in horses can be attributed to the great difficulty in palpating the anatomical structures necessary for this procedure because of the larger muscle layer. Although the animal in this report was young, without developed musculature, the local anesthetic application points were difficult to locate. Greater chances of blockade failure could lead to complications, such as intravenous injection, unilateral phrenic nerve palsy, laryngeal nerve palsy, intrathoracic injection, epidural or spinal anesthesia, and Horner's syndrome (VISCASILLAS et al., 2013).

As the surgical procedure may last for hours, ropivacaine was chosen for anesthesia, which lasts up to $6 \mathrm{~h}$ and is less cardiotoxic compared to bupivacaine (GARCIA, 2017).

During the surgical procedure, no major cardiorespiratory changes, such as tachycardia or tachypnea, were observed. There was an abrupt elevation of blood pressure, indicating a probable sensory block in the operated region. Considering the duration of the procedure and structures manipulated during the surgery, we hypothesize that the described regional anesthesia technique promoted numbness in the humeral region over a period of $130 \mathrm{~min}$.

\section{Conclusion}

The modified paravertebral cervical block for humeral osteosynthesis can be performed in young horses similar to that performed in small animals. Further studies on this technique in equine species are required.

\section{References}

BERRY, S. H. Anestésicos injetáveis. In: LUMB, W. V.; JONES, E. W. (Ed.). Anestesiologia e analgesia em veterinária. 5. ed. Rio de Janeiro: Roca, 2017. cap. 15, p. 271-290.

BUDRAS, K.; SACK, W. O.; ROCK, S. Axial skeleton and neck. In: BUDRAS, K.; SACK, W. O.; ROCK, S. Anatomy of the horse. 5. ed. Hannover: Schlutersche, 2009. cap. 3, p. 50-53.

CARPENTER, R. E.; BYRON, C. R. Técnicas de anestesia e analgesia locais para equinos. In: LUMB, W. V.; JONES, E. W. (Ed.). Anestesiologia e analgesia em veterinária. 5. ed. Rio de Janeiro: Roca, 2017. cap. 48, p. $880-905$.

CARVALHO, Y. K. Avaliação da anestesia paravertebral cervical no bloqueio anestésico local do membro torácico em cães. 2008. Dissertação (Mestrado em Anestesiologia) - Universidade Estadual Paulista, Botucatu.

DYCE, K. M.; SACK, W. O.; WENSING, C. J. G. Pescoço, dorso e coluna vertebral do equino. In: DYCE, K. M.; SACK, W. O.; WENSING, C. J. G. (Ed.). Tratado de anatomia veterinário. 3. ed. Edinburgh: Saunders, 2010. cap. 19, p. 496-501. 
GARCIA, E. R. Anestésicos locais. In: LUMB, W. V.; JONES, E. W. (Ed.). Anestesiologia e analgesia em veterinária. 5. ed. Rio de Janeiro: Roca, 2017. cap. 417, p. 327-349.

IMBELLONI, L. E.; BEATO, L.; GOUVEIA, M. A. Bloqueio do plexo braquial por via infraclavicular: abordagem ântero-posterior. Revista Brasileira de Anestesiologia, Campinas, v. 51, n. 3, p. 235-243, 2001. Disponível em: http://www.scielo.br/scielo. php?script=sci_arttext\&nrm=iso\&lng $=$ pt \& $\ln g=p t \& p$ id $=$ S0034-70942001000300007. Acesso em: 13 maio 2019. DOI: $10.1590 / \mathrm{S} 0034-70942001000300007$

JOCHUM, D.; IOHOM, G.; DIARRA, D. P.; LOUGHNANE, F.; DUPRÉ, L. J.; BOUAZIZ, H. An objective assessment of nerve stimulators used for peripheral nerve blockade. In: The Association of anaesthetists of Great Britain and Ireland Journal. WileyBlackwell: London Academic Publishing, 2006. p. 557564. Disponível em: https://onlinelibrary.wiley.com/ doi/full/10.1111/j.1365-2044.2006.04645.x. Acesso em: 14/05/2019. DOI: 10.1111/j.1365-2044.2006.04645
KLAUMANN, P. R.; PORTELA, D. A.; VILANI, R. G. D. C.; OTERO, P. E. Anestesia locorregional do membro torácico. In: KLAUMANN, P. R.; OTERO, P. E. (Ed.). Anestesia locorregional em pequenos animais. São Paulo: Roca, 2013. p. 177-212.

MORAES, A. N.; BEIER, S. L.; ROSA, A. C. Introdução à anestesia locorregional. In: KLAUMANN, P. R.; OTERO, P. E. (Ed.). Anestesia locorregional em pequenos animais. São Paulo: Roca, 2013. p. 65-95.

MURRELL, J. C. Agentes adrenérgicos. In: Anestesiologia e analgesia em veterinária. In: LUMB, W. V.; JONES, E. W. (Ed.). Anestesiologia e analgesia em veterinária. 5. ed. Rio de Janeiro: Roca, 2017. cap. 9, p. 175-187.

VISCASILLAS, J.; SANCHIS-MORA, S.; HOY, C.; ALIBHAI, H. Transient Horner's syndrome after paravertebral brachial plexus blockade in a dog. Veterinary Anaesthesia and Analgesia, Hatfield, v. 40, n. 1, p. 104106, 2013. Disponível em: https://www.vaajournal.org/ article/S1467-2987(16)30352-X/abstract. Acesso em: 14 maio 2019. DOI: 10.1111/j.1467-2995.2012.00770.x 